\title{
Från rösthörarnas värld - en analys av självbiografiska brev om hörselhallucinationer
}

\author{
LIS BODIL KARLSSON
}

\author{
Denna studie om hörselhallucinationer fokuserar på hur \\ fenomenet beskrivs i personliga brev från rösthörare. \\ Den undersöker vilka spräkliga konventioner som \\ används för att gestalta ett fenomen som tenderar att \\ patologiseras i vår kultur.
}

\section{Inledning}

En av många mänskliga företeelser är, vardagligt uttryckt, "att höra (inre) röster". Synonymer är (auditiva) hallucinationer, extraordinära fenomen, fantasier, hjärnspöken, hörsel- eller sinnesvillor, illusioner, inbillningar, röstförnimmelser, rösthallucinoser, tvångs- eller vanföreställningar, varsel, villfarelser, ibland självbedrägerier.

Studien fokuserar på självbiografiska brev om "att höra röster», alltså anteckningar om självupplevda erfarenheter av fenomenet. Syftet är, att analysera, hur människor kan beskriva och tolka sina upplevelser av rösthörande $\mathrm{i}$ text. Intentionen

Lis Bodil Karlsson är sociolog och doktorand i socialt arbete vid Stockholms universitet. Denna studie ingår $\mathrm{i}$ en avhandling om fenomenet watt höra röster" ur ett kommunikativt perspektiv är inte, att definiera fenomenet. Det kan dock avgränsas som någonting som erfars $\mathrm{i}$ vaket tillstånd, och uppfattas som en realitet, i motsats till att "tycka sig höra röster". Erfarenheten är ofrivillig till sin karaktär. Röster skiljer sig från tankar, som ses som delar av jaget, medan röster uppfattas som separata, utifrån kommande. Skillnaden är inte helt tydlig, eftersom tankar ibland kan "höras", som en inre röst.

\section{Rösthörande i olika sammanhang}

Inre röster betraktas vanligen som oproblematiska, om de hörs i nattens drömmar, mellan dröm och uppvaknande. Om röster är drömda eller "verkliga" kan likväl vara svårt att avgöra. Att höra röster är också naturligt, när en fantiserad figur talar till en 
dagdrömmare. Ytterligare exempel är barn, som leker med inbillade kamrater, eller när äldre "umgås» med avlidna (O'Mahony et al., 1984). I en religiös kontext kan inre röster vara accepterade, därför att de anses tillhöra ett gudomligt väsen eller för att de påverkar livet i religiös riktning (Geels, 1991). Forskning visar, att människor kan höra röster i olika sammanhang, $t$ ex vid traumatiska upplevelser, som sexuella övergrepp (Ensink, 1993), eller anhörigas död (Grimby, 1995; Rees, 1971) eller mandliga kriser" (Grof \& Grof, 1989; 1990). Assad och Shapiro (1986) relaterar rösthörande till biverkning av alkohol, droger eller legala mediciner. Fenomenet har även rapporterats vid neurologiska störningar förorsakade av demens, hjärnskakning, tumör eller infektion, öronsjukdom etc. (aa). Enligt Slade och Bentall (1988) kan andra fysiologiska orsaker till hallucinationerna finnas, t ex onormal kroppstemperatur eller brist på mat eller dryck (aa). Hörande av röster förknippas också med sinnessjukdom och förekommer hos patienter med diagnoser som schizofreni, depression, manodepressivitet eller dissociativ störning (Assad \& Shapiro,1986).

Tien (1991) menar, att vi vet mer om hallucinationer hos patienter än om sådana hos "normalbefolkningen". Tien åberopar ett antal studier, där ungefär 10\% vid ett icke kliniskt urval beräknas erfara hallucinationer. Dock finns inga longitudinella undersökningar. Tien hänvisar också till Sidgewick klassiska studie från 1894 med drygt 17000 respondenter från England, Brasilien och Ryssland. Antalet respondenter med erfarenhet av auditiva hallucinationer var 494, varav 169 hade sådana relaterade till uppvaknande eller insomnande. Tien (1991) refererar en större studie, som genomfördes mellan 1980-1984, med över 18000 respondenter i fem storstäder i USA, som visade att ca $2 \%$ hade erfarenhet av rösthörande (aa). I Posey och Loschs (1983) undersökning av 375 studerande hade $39 \%$ av dem, hört sina tankar, medan $5 \%$, uppgav att de samtalade med rösterna. Barett och Etheridge (1992) visade, att $37 \%$ av 586 undersökta studenter hade hört sina tankar. Ungdomarnas upplevelser kunde inte sättas i samband med psykisk ohälsa (aa).

\section{Olika beteckningar och förklaringar}

Beteckningar på och definitioner av rösthörande varierar mellan och inom olika förklaringsmodeller. Två vanliga modeller är den biomedicinska och den psykokognitiva. I dessa betecknas fenomenet som hallucinatoriskt (se Adler, 1997). Hallucinationer är illusoriska eller gäckande sinnesintryck, som inte motsvaras av yttre verkliga företeelser och indikerar patologi. I den religionspsykologiska modellen talas om profetior, uppenbarelser eller (auditativa) visioner (se Hillerdal, 1988), inom socialantropologin om besatthet eller trans etc (se Al-Issa, 1977; 1995; La Barre, 1975). Inom beteendevetenskaperna används, parallellt med hallucinationer, det vardagliga uttrycket att höra (inre) röster (se Boyle, 1993), så också inom den fenomenologiskt inriktade psykiatrin (se Bentall, 1993; Nayani \& David, 1996). Alternativa modeller uppfattar företeelsen som clairvoyance eller andlig vägledning, eller som uttryck för reinkarnation etc. (Romme \& Escher, 2000). 
Den medicinska modellen tenderar att reflektera ett biologiskt perspektiv, men inte ett socialt eller kulturellt. Al-Issa (1977) menar, att man inom den västerländska psykiatrin är intresserad av om en företeelse kan förklaras eller ej. Om orsaken till hallucinationen inte uppdagas betraktas den som patologisk. Hallucinationer av fysiska orsaker, som feber, hjärnskada etc. ses inte som psykiskt sjukliga. Drömmar är hallucinationer, om personen i fråga hävdar att hon inte sov. Andra aspekter som påverkar en psykiatrisk bedömning är om personen anser sig ha herravälde över upplevelsen eller om den upplevs som en fantasi. Dagdrömmar ses inte som abnorma. Människor som klassas som sjuka uppfattar rösterna som verkliga och som tillhörande utomstående (aa). Al-Issa (1977) tar upp en intressant lingvistisk fråga, vars svar avgör, om en upplevelse tolkas som en hallucination eller inte: "If the individual qualified his statements such as "it is as if I hear a voice» or "I imagined I saw Virgin Mary", this report is very unlikely to be labelled as hallucination« (aa, s. 168) (kursivering i orginal). Dock kan man vara psykiskt sjuk utan att hallucinera och tvärtom. Hörselfenomenen i sig, är inte handikappande, utan oförmågan att hantera dem, betonar Romme och Echer (1989).

\section{Sociala och kulturella tolkningar}

Av forskningen framgår inte vilka typer av människor som hör röster, utom att kvinnor i något högre utsträckning än män har sådan erfarenhet, enligt Tien (1991). Snarare är fenomenet situationsbetingat, efter- som människor hör röster i olika sammanhang. Kanske är förklaringen av upplevelsen också situationsbetingad. Om en inre röst uppfattas som tillhörande en fysiskt frånvarande, en avliden person, Gud, Djävulen, en ängel eller en demon eller om den framkallas av en drog, en psykos, en personlig förmåga eller någonting annat avgörs av den kommunikativa kontexten, dvs. sammanhanget i vilket den beskrivs och tolkas. Rösthörande bör inte betraktas som ett givet fenomen, utan fastställs genom en tolkningsprocess.

Konventionellt tenderar vi att uppfatta inre röster som monologa, dvs. att de utan någon kontext kommenterar eller kommenderar rösthöraren. Romme och Escher (2000) visar emellertid, att fenomenet bör relateras till rösthörarens liv. I stället för att betrakta röster som meningslösa, kan de ses som metaforer för inre eller sociala konflikter eller problem. I sitt arbete begränsar Romme och Escher sig inte till en traditionell biomedicinsk referensram, utan är öppna för alternativa tolkningar. Här ingår även beskrivningar av rösthörares upplevelser, men med inriktning på klinisk praktik. Forskarna betonar, att människor hör röster, inte att de lider av mystiska auditiva hallucinationer. En sådan terminologi komplicerar bara rösthörarens bearbetning av sina erfarenheter (aa).

I några studier av auditiva hallucinationer fokuseras på rösthörares attityd till sitt språk (se Leudar et al, 1992; 1994;1997). Leudar et al. (1997) anser, att inre röster uttalar vad rösthörare själva vill säga, vilket också är till nytta för tankelivet, som vid problemlösning. En uppenbar skillnad finns dock, jämfört med vardagligt inre tal. 
I sådant uppfattas inre röster som rösthörares egna, men i rösthörande som andras (aa). Leudar och hans kollegor menar, att rösterna oftast är vardagliga och rösthörares reaktioner okomplicerade. "The most common function of voices seems to be to regulate activities of voice hearers. Voices do this dialogically by issuing directives, evaluatives and questions" (aa, s. 892). Forskarna betonar rösternas dialogiska form, som deras enkla uppmaningar, $t$ ex att stänga eller öppna dörrar. För det mesta ignoreras rösternas kommentarer, vilket ofta resulterar i att de insisterar eller blir högljudda. Den andra dialogiska dimensionen är att rösterna bedömer rösthörares intentioner eller handlingar, och den tredje är att de frågar rösthörarna om olika aktiviteter, men även, att rösthörare kan fråga dem om $t$ ex deras rätt att döma: „This means that verbal hallucinations are also organized as reversible question-answer sequences - both voices and voice hearers asking questions and providing answers" (aa, s. 895). Den fjärde aspekten av rösternas dialoga struktur handlar om att de informerar rösthörarna om olika företeelser. De uppfattas som en exceptionell form av människors inre talförmåga (inner speech). "They are of course a rather odd kind of inner speech, because one hears it without speaking and the degree to which it is considered ego-alien is exaggerated" (Leudar et al., 1997, s. 896).

Rösthörande är en allmänmänsklig erfarenhet (universal human experience) genom historien och i alla kulturer, anser Al-Issa (1995). Några gemensamma nämnare genom tiderna finns, menar Leudar och Thomas (2000), som att bara få män- niskor har erfarenhet av att höra röster, att rösterna hörs när andra människor är frånvarande och att rösterna kommenterar vad rösthöraren gör och tycker. Enligt forskarna finns emellertid inte ett entydigt svar på frågan: Vad är fenomenet "att höra röster»? Frågan låser in i ett för snävt tänkande, som utgår från att det finns en ursprunglig erfarenhet av att höra röster, som återkommer $\mathrm{i}$ alla historiska tider, samt att det finns en föreställning av fenomenet som är och förblir densamma. Forskarna betonar att rösthörande är beroende av kontext (context-contingent). Om Leudar och Thomas först uppfattade röster som ett för jaget främmande inre "tal" (inner speech), så fann de sedan, att denna idé hindrade dem från att förstå rösthörares erfarenheter, särskilt om deras föreställningar skiljde sig från forskarnas. Som exempel nämns den av Freud analyserade patienten Schreber För att överhuvudtaget förstå Schrebers resonemang om sina röster, måste Leudar och Thomas överta hans tänkande för att förstå logiken i hans erfarenheter. Forskarna reviderar sin uppfattning och fokuserar på rösthörarnas egna redogörelser och hur rösterna påverkade umgänget med andra människor (Leudar \& Thomas, 2000).

\section{Metod och material}

Intentionen med att efterlysa brev om personliga upplevelser av rösthörande var att låta rösthörare reflektera ostört för att undvika regisserade intervjuer och berättelser, som inte var informanternas utan intervjuarens (se Mishler 1986). Personliga dokument, som kommer till stånd $\mathrm{i}$ ett forskningssammanhang (research-gene- 
rated), har nackdelar, men också fördelar, enligt Hammersley och Atkinson (1995). De är partsinlagor, men är inte mindre autentiska eller spontana än muntliga berättelser (aa). Informanterna skulle i föreliggande fall få uttrycka sig, utan att hindras av talspråkliga konventioner eller forskarens fysiska närvaro. Helt fria var de dock inte, ty litterära konventioner kunde styra. Konventioner finns dock för all mänsklig kommunikation.

En inledande svårighet var, att definiera "att höra röster». Många potentiella informanter kanske hör röster, utan att reflektera över detta, och uppfattar kanske dem som sina tankar. Avsikten var, att nå informanter, patienter eller ej. Informanterna fick därför själva avgöra, om de hör(t) (inre) röster eller inte och om de skriftligen ville berätta om sina erfarenheter. Rösthörare är, i denna studie, således den som uppfattar sig som sådan. En osäkerhet var om undersökningen skulle begränsas till informanter, som uppfattades som avvikande. Men att människor stämplas, officiellt eller inofficiellt, diskvalificerar dem inte i forskningssammanhang.

\section{Urval}

Brevberättelserna efterfrågades under 1998-2000 i Revansch, medlemstidning för Riksförbundet för Social och Mental Hälsa (RSMH), och i Vi hörs, nyhetsblad för Rösträtt - ett nätverk för rösthörare. Annonser placerades i andra tidskrifter eller tidningar under rubriken Meddelanden eller på Familjesidan. I tabell 1 redovisas, var annonsen/uppropet fanns att läsa. Med upprop avses, att frågorna publicerades som redaktionell text och med annons, att de publicerades mot betalning.

Medlemmar i en patientorganisation är inte representativa för landets befolkning. Många lever av förtidspension eller sjukbidrag, har hög ålder och har haft upprepade sjukhusintagningar med långa vårdtider. De omfattar förmodligen rörelsens ideologi och/eller söker kanske en grupptillhörighet. Syftet med annonserna var, att även nå rösthörare, som inte tillhörde förbundets medlemskader, som inte hade erfarenhet av psykiatrisk behandling och som hade annan bakgrund ifråga om ålder, social ställning, utbildning eller medborgerligt ursprung. Tanken var också, att informanterna skulle kunna belysa olika aspekter av rösthörandet.

Rösthörande kan av flera skäl vara svårt eller omöjligt att berätta om, kanske tabu. Rösterna kan förbjuda rösthöraren att tala om dem. De kan också vara allt för personliga och intima att beröra, kanske även för anhöriga. Somliga rösthörare vill gärna berätta, men kanske inte allt. Informanters självselektivitet och självcensur kan jämföras som med hur skriftliga enkäter besvaras. Motivation krävs för att avsätta tid till att skriva. Informanterna kanske försöker ge socialt acceptabla redogörelser, eller på annat sätt framställa sig i fördelaktig dager. Med olika metoder når forskaren olika grupper. Den valda metoden hindrade somliga potentiella informanter att delta i studien, men gjorde detta möjligt för andra, trots exempelvis fysiskt handikapp, hög ålder eller social fobi. Uppropen/annonserna begränsade urvalet till dem som ville, och trodde sig kunna, kommunicera skriftligen. De flesta av informanterna hade patienterfarenhet, men inte alla. Urvalet 
av informanter var inte möjligt att betrakta som representativt, utan måste uppfattas som en tillfällig samling, från vilken några slutsatser om hela gruppen rösthörare inte kunde dras. Däremot kunde breven utnyttjas för att analysera olika sociala och kulturella konventioner om rösthörande.

Totalt inkom 44 brev, varav tre var tillägg till ett första brev, informanterna var alltså 41. De hand- eller maskinskrivna eller ordbehandlade breven skrevs ordagrant av, utan någon redaktionell bearbetning, och blev mellan 20 ord och drygt 17 sidor lång ordbehandlad text, i genomsnitt mellan tre och fyra sidor. Varje brevskrivare avidentifierades genom att namn, bostadsort eller annan privat information ändrades. Några informanter avslöjade sin ålder. Äldst av dem var en kvinna, 94 år, och yngst en 29 årig man. Uppgifter om ålder saknas för majoriteten, därför kan här bara konstateras att olika generationers förutsättningar sannolikt påverkar respektive respondent. De flesta dokumenten såg ut att ha tillkom- mit på grund av uppropet/annonsen. Två informanter skrev, att de inte hade något att berätta, men berättade ändå. Dessutom erhölls fyra vykort med hälsningar, som dock ej ingick i analysen, ej heller ett brev, som innehöll en uppmaning att forska om psykiatrins övergrepp. Ett av breven var inte undertecknat, och informantens kön var okänt. Det framgick inte heller av texten. Av de övriga informanterna var tjugofyra män och sjutton kvinnor. Ett anonymt brev förmedlades av psykiatrin. Kön och ålder angavs däremot. Alla breven var läsliga, utom ett som var omöjligt att tyda på grund av handstil, ofullständiga meningar och blandning av flera språk. Varför fler män än kvinnor svarade var svårt att avgöra. Av dem som svarade på annonsen utanför patientorganisationen var dock fler kvinnor än män (se tabell 1).

\section{Bearbetning av materialet}

Analysarbetet genomfördes parallellt med

\section{Tabell I.}

Översikt över upprop och annonser

\begin{tabular}{|c|c|c|c|}
\hline Tidning/tidskrift & Målgrupp & Antal svar & $\begin{array}{l}\text { Placering \& } \\
\text { tidpunkt }\end{array}$ \\
\hline Revansch! & Medlemstidning & $\begin{array}{l}\text { I } 8 \text { män, } 9 \text { kvinnor, } \\
\text { lanonym }\end{array}$ & $\begin{array}{l}\text { Redaktionell text, nr 3, } \\
\text { nr 5-6/1998, nr I/1999 }\end{array}$ \\
\hline Vihörs & Nyhetsblad & 5 män, 3 kvinnor & Som bilaga 1999,2000 \\
\hline Sydsvenska Dagbladet & Regionaltidning & 2 män & Familjesidan 4/I0 1998 \\
\hline Dagens Nyheter & Morgontidning & I man, 3 kvinnor & Familjesidan I/I 1999 \\
\hline Tidningen Dagen & Kristen dagstidning & I kvinna & Familjesidan I/3 1999 \\
\hline Örnsköldsvik & Regionaltidning & I kvinna & Familjesidan I/I 1999 \\
\hline \multirow[t]{2}{*}{ Tidningen Hälsa } & Månadstidning & Inga & Annons maj 1999 \\
\hline & & $\begin{array}{l}\text { I Anonym, } 26 \text { män och } \\
\text { I } 7 \text { kvinnor, sammanlagt } \\
44 \text { brev }\end{array}$ & \\
\hline
\end{tabular}


insamlingen av breven. Det skedde stegvis, och började redan vid transkriberingen. Noggrant motlästes varje transkriberad text och jämfördes med det ursprungliga brevet. I detta skede assisterades jag av en person med erfarenhet av psykoser, som bidrog med sin kunskap ur ett vardagligt perspektiv. Våra gemensamma reflektioner dokumenterades. Under den fortsatta bearbetningen jämfördes dessa anteckningar med alternativa tolkningar. I nästa steg lästes de transkriberade texterna igenom, sammanlagt 161 sidor, för att söka efter återkommande teman i varje dokument, väl medveten om att annonsens/uppropets formulering skulle styra varje svar. Dock varierade breven till såväl innehåll som form. Det första temat handlade om hur informanterna beskrev upplevelsen "att höra röster". Det andra temat var hur respondenterna förklarade sina röster. Det sista temat, var hur informanterna hanterade sina erfarenheter, alltså deras strategier.

Det tredje steget innebar, att systematiskt gå igenom texterna för att kategorisera varje brev efter hur varje informant framställde sina röster, tolkade dem respektive formulerade sin strategi för att bemästra dem. Intentionen var, att i varje dokument, som Malterud (1998) skriver, söka efter "meningsbärande enheter" (aa, s. 92). Så erhölls en översikt över informanternas texter i form av en matris med koderna Framställning, Tolkning och Strategi. Senare tillkom en kod, Organisering, som avsåg hur informanterna strukturerade sina texter med hjälp av litterära konventioner, som relationen till tid och rum, t ex om händelserna ordnades kronologiskt och rumsligt.
Det fjärde steget innebar, att bearbeta texterna under varje kod. I denna artikel redovisas under rubriken Att beskriva och förklara inre "röster", hur informanterna framställde och tolkade sina röster respektive vilket förhållande de hade till dem. Ursprungligen betraktades breven som de annorlundas monologer, där informanterna berättade om händelser i sina liv, samtidigt som de försökte förhålla sig till fenomen som tenderar att patologiseras i vår kultur. Vid genomgång av texterna under koden Organisering upptäcktes, att de flesta breven inte alls hade en monolog utan en dialog struktur. De textanalytiska termerna monolog, dialog och polyfoni, utvecklade av Bachtin (1991), kom därför att inspirera den fortsatta bearbetningen ${ }^{1}$. I författarskap som kännetecknas av polyfoni, flerstämmighet, skildras och talar huvudpersonerna som tänkande subjekt. Polyfoni, använder Bachtin metaforiskt, för att klargöra att olika figurer framställs med ett självständigt medvetande, oberoende av författarens. Deras människosyn och uppfattning om världen är inte författarens. I en monolog text däremot, får figurerna beskriva händelser, andras karaktär eller uttrycka författarens åsikter. Dostojevskijs romaner är, enligt Bachtin, dialogiska, vilket innebär, att olika medvetanden ställs mot varandra, utan att bli objekt för varandra. En passage som redovisar romanhjäl-

1 Litteraturvetenskapliga begrepp har sina begränsningar. Romaner är fiktiva, även om allmänmänskliga fenomen berörs, medan breven i studien var dokumentära. Bachtin uppfattade emellertid litterära texter som tillförlitliga källor till social kunskap, enligt Aronowitz (1995). 
tens tankar uppfattas vanligen som en inre monolog, men är egentligen en mikrodialog, en inre intensiv monolog mellan olika röster, vilka för en dialog: „Dialogen har trängt in $i$ varje ord och i dess inre framkallat en kamp mellan röster som avbryter varandra» (aa sid. 83). Ännu en typ av dialog finns, den dolda dialogiciteten, vilken innebär, att även om en andra persons ord inte hörs, påverkas den första personens ordval. Vi uppfattar det som en konversation, trots att bara en person yttrar sig, eftersom varje ord är en reaktion till den osynliga talarens outtalade ord.

I denna artikel presenteras det empiriska materialet i flera steg. Först anges hur informanterna beskrev och förklarade sina röster. Sedan följer avsnittet Att ordna berättandet i tid och rum, vilken handlar om stilistiska grepp för att ordna sin historia. Avsnittet Brevens dialoga struktur redovisar varianter av retoriska strategier för att berätta om rösterna, som vilka element som användes i breven, t ex dialog och polyfoni.

\section{Att beskriva och förklara inre röster}

Informanterna betecknade sitt rösthörande olika. Det omnämndes ofta som röstförnimmelser, (att) hör(a) röster, min (inre) röst, mina (inre) röster eller rösten/rösterna. Ibland skrevs (tankar) efter eller före röster. Orden markerades emellanåt med citat, som »röster(na)« eller »hör(a) röster». Någon gång uppfattades fenomenet som en exceptionell förmåga, som en "mycket god hörsel som gick genom vilka väggar som helst", eller som "(hörsel/röst)hallucinationer" eller hallucinerande. Ibland användes egna ord eller uttryck, som "röstupplevelser", "rösterfarenheter", "mina 'hörselproblem' ", "en mycket stark röstkänsla», "min goda röst", "en röst i huvudet" eller "tomtarna på loftet». Det possessiva pronomenet min(a) indikerade upplevelsens subjektiva karaktär.

Rösterna kunde vara få- eller mångordiga. De kanske bara skrattade, viskade eller frambringade andra läten. Ibland hördes musik eller mekaniska ljud, som från ett tåg. Rösterna hördes genom öronen, inne $\mathrm{i}$ huvudet eller i någon annan kroppsdel. De kunde låta som andras tjat, ett bakgrundsmummel, en hejarklack, störande ljud från grannar eller en auktoritär föräldraröst. De kunde vara starka eller svaga. De beordrade, rådde, kommenterade, tröstade, nedvärderade eller hotade, ropade rösthörarens namn, siade om framtiden eller visste allt.

Informanterna beskrev sig själva och sin relation till sina röster, som en tillgång eller som en belastning. Flera karaktäriserade dem som emellanåt skrämmande, otäcka och deprimerande. Ibland kunde rösterna berätta om grandiosa religiösa visioner eller annorlunda upplevelser. Andra beskrev dem som eviga följeslagare, som alltid kommenterade allt de gjorde eller planerade att göra. För ytterligare andra var erfarenheten något tillfälligt. Informanterna beskrev sina röster ibland svepande, ibland detaljerat. Emellanåt nämndes också andra annorlunda upplevelser, som syner eller beröringar. Rösterna uppfattades inte allid som psykiatriska symtom, utan hade med religiösa föreställningar, konflikter, livskriser eller trauman, att göra. De kunde komma från det "undermedvetna", från drömmar, från 
egna eller andras tankar (genom telepati), från svart magi, från ingenstans eller från en annan värld, från bilarnas fartvind eller från inopererade datorchips. En inre röst kunde tillhöra en fiktiv eller verklig personlighet, levande eller avliden. Den kunde även uppfattas som Guds, som Djävulens, som en ängels eller som en ond andes röst. Några informanter uppfattade sina röster som verkliga, andra inte. Ytterligare andra skiljde på vad de trodde om rösterna när de inte längre hördes. Skillnaden mellan (inre) röster och tankar verkade ibland vara oklar, likaså mellan sjuka röster och friska. En informant, Josefin, skiljde mellan varsel, tankeöverföring och rösthörande. Varsel var sådant som "inte [kunde] förklaras", t ex när hon som barn hörde sin mors fotsteg $i$ trappan en stund innan modern kom hem. Tankeöverföring var viss kommunikation mellan Josefin och hennes son. Om hon funderade på något kunde sonen säga "Jo, morsan..." och sedan uttrycka tankar liknande hennes. Rösthörande förekom i vissa kritiska situationer, som när Josefin under en förlossning hörde sin mors röst, eller i kriser, när hon bett till Gud och hört hans röst.

Alla breven var jagcentrerade, dvs. skrivna $i$ jagform, med de inre rösterna som motpart, vilket kommenterades i ett av följebreven: »Jag har valt att skriva det $\mathrm{i}$ direkt form även om jag nu har distans till det hela. Meningen är väl att andra ska kunna förstå hur det upplevs(?)« Breven handlade ibland om svårigheten att hantera rösterna, särskilt plågsamma eller retsamma sådana. En brevskrivare betonade att rösterna inte var förnimmelser, "utan röster som man uppfattar som lika verkliga som de röster som man normalt hör med öronen«. De var "verklig kommunikation mellan två, eller flera parter«. Han förtydligade genom tilllägget: „Man får hela grejen röstläge betoning etc dvs exakt som om det var röster som hörs via örat." Emellertid hördes inte bara röster, utan han kunde även kommunicera med rösterna genom gester, således förmedlades »orden via små vanliga gester, en liten handrörelse, en lätt vridning på huvudet etcu. En respondent uppfattade sina röster som förnimmelser, $i$ form av wimpulser hur man skall tänka och hur man skall handla" och hon kunde "förnimma stavelser och ord, så tydligt som om man läser en textremsau.

\section{Att ordna berättandet i tid och rum}

Rösthörarna använde litterära konventioner för att förmedla sin historia. Några berättade kronologiskt, dvs. de ordnade händelserna som förknippades med rösthörande, tidmässigt. De knöt rösterna till livsavgörande förändringar. I sina texter dröjde de vid biografiska händelser, som familjebildning, giftermål, skilsmässa, anhörigas död, början eller avslut på studier etc. Relationen till rösterna kunde förändras med personens liv. Således behövde rösthörandet inte vara en isolerad upplevelse, i stället kunde det markera en övergång $i$ livet då respondenten fattade avgörande beslut. Alla brevskrivare ordnade inte sin berättelse i tidsföljd. En del nämnde inte ens dimensionen tid. Att utnyttja tiden som ett retoriskt grepp var naturligtvis inte självklart. Brevskrivarna kunde i stället utgå från rummet, dvs. platsen, där allt utspe- 
lade sig. När rumsliga metaforer användes blev tiden sekundär. Berättare och röster eller andra personer rörde sig in i och ut ur rummet eller den psykotiska världen. En brevförfattare skrev, att han ibland gjorde »en djupdykning i rösthörarvärlden». En annan berättade om sin väg "ner i vågdalen, för att inte säga avgrunden«. En tredje skrev, hur demonen lockade henne med löften om ny kunskap. Vissa situationer kunde försätta henne, från ena stunden till en annan, »i en annan värld, en värld där en auktoritär röst befann sig och berättade för mig att nu är det nära, nu har kvinnan och jag en hemlighet. (...) Rösten inom mig tog mig till oanade höjder.«En fjärde förklarade att hon vid en livskris inte längre kunde kommunicera med sina anhöriga. Detta skildrades som att hon gick vilse: "Jag hittade inte utvägen, jag hade tappat bort den och tappade kontakten med min familj, (...) mina föräldrar och syskon och även vänner såg mig försvinna (...)«. En femte, Benedict, beskrev i ord en Hieronymus Bosch-liknande triptyk av skräck: Den första bilden visade, hur han som mörkrädd sexåring låg i sitt rum och såg hur möblerna "formades till skrämmande gestalter». Den andra bilden framkom när han bad:

flera böner för att slippa fler uppenbarelser av den typen. Då syntes ett starkt ljus som formades till en ängel. Frid uppfyllde mig. Jag hörde en röst som talade till mig. Den sa till mig. Du har funnit frid hos herren. Du skall som vuxen söka upp ateistiska vetenskapsmän. För dem skall du göra under som bevisar min existens för dem. De skall kunna göra vetenskapliga undersökningar av undren. Sedan lämnade denna ängel mig.
Den tredje bilden framställde, hur Benedict dömdes till döden, korsfästes och igen hörde en röst, som sade: "Du har funnit frid hos herren. (...) Rösten sade att jag som vuxen skulle bevara medicinsk information om människor åt framtidens läkare». Rösten tröstade. Mörker ersattes av starkt ljus, som förvandlades till en (talande) ängel. Under en skräckfylld och drömliknande upplevelse hördes Guds(?) röst. Benedict tolkade inte sina erfarenheter, utan nämnde de intensiva auditioner och visioner han hade som barn. Hans röster var uppenbart bibliskt influerade och beskrevs med en religiös retorik. Kärnan i berättelsen var det övertydliga religiösa budskapet om tröst och upprättelse. Han målade en bild av sin vistelse i ndet psykotiska rummet«. Möblerna i hans barnkammare förändrades till otäcka levande figurer. Oväntade religiösa upplevelser av auditiv och visionär karaktär börjar ibland med ett starkt ljus, enligt Geels (1991). Vi kan bara gissa, varför brevskrivaren hade dessa upplevelser. Förr kanske Benedict skulle ha betraktats som ett religiöst underbarn. $\mathrm{Nu}$ kanske han ses som ett ensamt och utsatt barn med fantasi.

En kvinnlig brevskrivare, Patricia, berättade, att hon på grund av en virussjukdom isolerades på en infektionsklinik, vilket beskrevs som "psykotikerns värsta mardröm»: "Mat och medicin sattes in genom en lucka i väggen. Ville jag personalen något skulle jag ringa, och då kunde jag tala med någon genom en högtalare som satt högt uppe på en vägg." Efter några dagar gick hon in i psykosen, efter att förgäves bett att få tala med någon för att bryta sin isolering. Patricia gick in i det "psykotiska 
rummet», en metafor för en intensiv själslig upplevelse utöver det vanliga:

Men från hålet $i$ väggen meddelades bara att detta var en somatisk klinik. De hade ingen psykologservice att erbjuda. Då började jag själv tala till hålet och hålet svarade. Först pratade hålet och jag om väder och vind, precis som nybekanta. Det hade dragit fram en kraftig snöstorm, och rododendron-buskarna på den lilla innergården var begravda under snödrivor. Jag undrade om jag själv snart skulle begravas och hålet svarade att det var högst troligt men att jag nog skulle återuppstå till våren. Det lugnade mig, för jag såg fram emot sommaren då mitt blod skulle vara rent och min kropp färdig att ta emot nästa lilla barn. Då började hålet skratta àt mig. Det hade ett rutigt galler över sig, som en fäktares mask, och både språket och skrattet blev allmera rutigt. Fläktmasken förvandlades till slaktmask, och blod började rinna nerför de vita väggarna. (...)

Slaktmasken hade uppmärksammat att jag inte hade någon TV och snart fanns all själens kanaler på de blodstrimmiga väggarna. Det kom också ett malande rymdtjatter, och ingenting gick att stänga av. Det enda som var oföränderligt var de vita sulfatabletterna som sattes in i luckan var fjärde timme.

Närjag skrevs ut till hemmet med alla sulfaburkar var jag oerhört trött och gladde mig àt att komma hem och äntligen få lite lugn och ro. Men $i$ mitt hem hade redan hela sällskapet flyttat in och väntade på mig. Hålet fanns där redan före mig och hälsade mig välkommen hem med gapskratt och vederbörligt pladder.
Patricias inre röst presenterades som en ny bekantskap när den introducerades i brevet. Hon och "hålet i väggen« började konversera för att lära känna varandra. Rösten skrattade, pratade och kunde till och med uppfattas som ett "medvetande». Den observerade hennes förehavanden och hånade henne. "Rösten" antog också andra "fysiska skepnader", som en fäktmask, en fläktmask och en slaktmask och blev så småningom ett helt sällskap. Det utvecklades inte till en polyfoni utan till, något som skulle kunna karakteriseras som, en kakofoni av röster, när de blodstrimmiga väggarna i sjukhusrummet gav röst åt alla "själens kanaler". Patricia kunde inte stänga av ljuden. Det "psykotiska rummet", tog överhanden. Det enda som markerade tiden var "de vita sulfatabletterna som sattes in $\mathrm{i}$ luckan var fjärde timme». Det skrattande och pladdrande "hålet» flyttade till och med hem från sjukhuset.

Det berättande jaget i Patricias text kan uppfattas som flera olika jag. Så gjorde det psykotiska jaget sin entré när hon började tala till hålet. I en annan passage var jaget den kvinna som ville bli frisk nog att kunna föda ett nytt barn. Men "hålet» drog in henne igen och snärjde henne i en psykos. I en tredje passage tröstades hon av sitt döda barn, och ville stanna på infektionskliniken. Återigen var jaget en kvinna i vardagen, ett icke-psykotiskt jag, som inhandlade pärlemorknappar och stickade en babytröja. Rösten bakom slaktmasken var Patricia dock övermäktig och hon måste söka sig till psykiatrin: „Men den kväll när jag insåg att hela kroppen var fylld av kokta risgryn och höll på att spricka - ur armarna vällde kokta risgryn fram och jag födde gröt 
med lingonsylt, åkte jag till psykkliniken.» Brevskrivaren presenterade sig åter som ett psykotiskt jag genom denna bild och skildrade upplevelsen av hur hennes jag höll på att lösas upp.

\section{Brevens dialoga struktur}

Breven hade i allmänhet en dialog struktur. Tre olika typer av dialoger kan urskiljas i dem. För det första, en dialog mellan brevskrivaren och forskaren, som har uppmanat till brevskrivande och därmed kommunikation kring rösthörande. För det andra, mellan brevskrivaren och rösterna, när hon försöker att förstå och tolka rösterna, varifrån de kommer och vad de vill. För det tredje, finns en dialog mellan karaktärer och röster, i grunden en dialog mellan rösterna.

\section{Dialogen med forskaren}

För brevens författare kunde adressaten förnimmas som samtalspartner, och i breven anteciperades mottagarens möjliga respons. Några av informanterna riktade de första raderna till forskaren, som: "Jag fick för någon vecka sedan tidningen Revansch? i mina händer. Och jag läste igenom den och kom till ditt "Upprop till dig som hör röster!ณ. Eftersom jag har en viss erfarenhet av det så delar jag gärna med mig av mina upplevelser." I andra dokument återgavs delar av rösthörarens inre dialog eller en "mikrodialog" (Bachtin, 1991). Här redovisas ett brev i sin helhet där alla ovan nämnda dialogtyper återfinns, Edvard skriver:

Jag hör röster och jag tycker inte om det. Vad jag än gör går de inte bort Jag hörde röster första gången, när jag var 18 år gammal. Den förklaringen till att jag hör röster. Det är att tankarna kommer från mina föräldrar, skolan. Att tankarna är redan inplanterade $i$ (ungdomen), barndomen. Någonstans måste de komma ifrån. Jag hör en massa röster som vill nedvärdera det jag gör, som inte alls gillar mig. Ibland tycks de hata mig. Jag kan inte förstå varifrän som den synen kommer, om det var mina föräldrar som ville att jag skulle tycka illa om mig själv. Jag försöker att fä bort mina tankar, (h) eller röster med viljan. Men i de flesta fall lyckas det dåligt. Jag tycker inte om det, och medicinen verkar dåligt på röster. Jag behöver ingen hjälp med rösterna. Jag har talat om det, men jag tycks inte ha nagon reaktion. Det tycks vara som att det finns inget sätt att bota röster på. Jag har sökt hjälp men det tycks inte funnas någon hjälp. Nåt som man måste leva med. Det är inte normalt att höra några röster, det är sjukligt.

Edvard skrev inte, vad rösterna sade, men att de hade sitt ursprung i barndomen och de underkände honom. I detta brev vände sig informanten direkt till forskaren och besvarade också frågorna i annonsen/ uppropet, vilket också andra informanter gjorde. Deras brev kunde uppfattas som delar av en dialog, som Bachtin (1991) benämner den dolda dialogiciteten, alltså en dialog där den andres uttalanden utelämnas, men dock påverkar den första personens ordval. Varje ord är således ett svar till den osynliga talaren. Brevet ovan visar hur det i själva verket bygger på en dialog. Om tänkta frågor från forskaren skjuts in i texten visade det sig, att den hade en tydlig dialogisk struktur. 
- Hur är det att höra röster?

Edvard: Jag hör röster och jag tycker inte om det.

- Hur vill du beskriva dina röster?

Edvard: Vad jag än gör går de inte bort. Jag hör en massa röster som vill nedvärdera det jag gör, som inte alls gillar mig. Ibland tycks de hata mig. Jag kan inte förstå varifrån som den synen kommer, om det var mina föräldrar som ville att jag skulle tycka illa om mig själv.

- När hörde du röster för första gången? Edvard: Jag hörde röster första gången, när jag var 18 år gammal.

- Vad tror du är förklaringen till rösten eller rösterna?

Edvard: Den förklaringen till att jag hör röster. Det är att tankarna kommer frän mina föräldrar, skolan. Att tankarna är redan inplanterade $i$ (ungdomen), barndomen. Någonstans måste de komma ifrån.

- Hur försöker du hantera dina röster?

Edvard: Jag försöker att få bort mina tankar, (h) eller röster med viljan. Men $i$ de flesta fall lyckas det dåligt. Jag tycker inte om det, och medicinen verkar dåligt $p a ̊$ röster.

- Har du berättat för någon annan om dina röster? I vilket sammanhang? Behöver du hjälp av andra för att hantera dina röster?

Edvard: Jag behöver ingen hjälp med rösterna. Jag har talat om det, men jag tycks inte ha någon reaktion. Det tycks vara som det finns inget sätt att bota röster på. Jag har sökt hjälp men det tycks inte finnas någon hjälp. Nåt som man måste leva med. Det är inte normalt att höra några röster, det är sjukligt.
Texten kunde alltså uppfattas som en dold dialog, därför att den andres frågor inte redovisades. Rösterna underordnades därmed författaren i hans dialog.

\section{Den inre dialogen}

Dokumenten antydde förekomsten av dialoger mellan brevskrivaren och rösterna, då rösterna skiljs från författaren och blir självständiga. Dialogerna uttryckte rösthörares försök att förstå och tolka sina röster, varifrån de kom och vad de ville. Flera respondenter betraktade sina röster som samtalsbara eller som "sällskap", som de kunde kommunicera med (se Patricia). En informant, Ulrik, skrev, att hans röster först bara hördes som ett sorl, men när de sedan ändrade karaktär kunde han samtala med dem:

"Jag mådde mycket bra $i 9$ mån., sen så började helvetet igen, - men med den skillnaden att nu är rösterna klara och tydliga.

Min första tanke var att vad fan gör $d u n u$ Ulrik?!!

Men jag tänkte - jag börjar att svara tillbaka - sagt och gjort - jag började att svara denna röst. Jag förde regelrätta samtal, som om jag pratade med vem som helst. Det är ju klart, att folk på bussen vände sig om ibland och funderade, men jag tänkte att: Nu är det som det är, det kan jag ej hjälpa!"

En annan informant förundrades, när han började höra en röst: "Jag blev förvånad, jag visste inte vad jag skulle tro, var det en röst från yttre rymden eller var det en mikrofon inuti huvudet ljudet kom ifrån." Rösterna jämfördes ibland med tänkande

Lis Bodil Karlsson: Från rösthörarnas värld - en analys av självbiografiska brev ... 
eller så formulerades breven som uttryck för introspektion. Skillnaden mellan (inre) röster och tankar kunde ibland vara oklar, som i följande text av Anja. Så här började brevet:

$J a g$ "hör röster $i$ nära känslomässiga kontakter. "Rösterna" är en berättelse om vad den andra människan tänker om o "gör med" mig. Rösterna eller tankarna stämmer ofta med verkligheten på olika plan o jag utgår ifrån att jag har någon form av medial förmåga i botten.

När respondenten i sitt brev nämnde att hon hörde röster sattes orden inom citat. Flera gånger skrevs (tankar) efter eller före röster. Skillnaden mellan röster och tankar tycktes vara försumbar, kanske synonyma. Rösterna ansågs tyda på en "medial förmåga», därför att de avslöjade vad andra människor tänkte och gjorde. Gränsen mellan (inre) röster och tankar verkade flyta i dokumentet. Även Edvard jämställde röster med tankar. Med anledning av rösternas kritik skrev han: „Jag kan inte förstå varifrån som den synen kommer, om det var mina föräldrar som ville att jag skulle tycka illa om mig själv«. Edvard ville förstå rösternas ursprung och mening. Han såg tillbaka och hittade en förklaring i barnets svårigheter att avvärja vuxnas klander. Rösterna var tankar, som wredan (var) inplanterade i (ungdomen) barndomen". Men han var inte helt säker. Det var som om han riktade sig till sig själv när han skrev att rösterna måste ha en förklaring: "Någonstans måste de komma ifrån. "Dessa meningar var fragment av brevskrivarens dialog med sig själv om rösterna, alltså en inre dialog. Edvard behövde inte någon hjälp med sina röster och hade också framfört detta, men till vem framgår inte. För honom fanns ingen hjälp att få. Vad han än gjorde, så försvann inte hans röster/tankar. Även om Edvard fann en psykologisk förklaring till dem, betraktade han dem som onormala, till och med som sjukliga. Ett barn vill egentligen aldrig tro sig vara oälskat av föräldrarna. Om rösthörandet är en psykisk sjukdom fritages föräldrarna och andra vuxna från skuld.

Även om »rösten« till och med lät som den egna rösten, måste inte det hörda accepteras som egna tankar, eller som en av respondenterna beskrev sin röst: „Det är som tankar som jag hör högt men det stämmer inte med mina egna tankar. Rösten säger ofta elaka saker (...) som jag inte alls håller med om." Olika röster kunde ibland vara i dialog med varandra och uppfattas som separata eller skilda från författaren, vilket kommer att beröras i nästa avsnitt.

\section{Karaktäreridialog}

Handlingen i dokumenten kretsade alltid kring informanten. Författaren och huvudpersonen i dokumenten var samma person. Ingen natur eller miljö beskrevs, utom i en text, men där hade miljön en funktion i händelseförloppet (se Patricia). Informanterna berättade om sina upplevelser och om sin syn på sig själva och sin värld. Alla handlingar i breven rör huvudpersonen. Andra aktörer introducerades, när de hade en uppgift i berättelsen. De människor som figurerade i dokumenten var anhöriga, släktingar, vänner eller bekanta. Andra kunde tillhöra psykiatrin, såsom mentalskötare, kontakt- 
män, psykiater eller terapeuter. Vissa uttalanden tillskrevs ibland en bestämd person. Berättaren kunde därmed uttrycka olika, ibland motsägelsefulla ståndpunkter, utan att själva ta ställning. En informant kunde låta olika personer komma till tals, t ex om han inte själv visste, hur han skulle förklara sina röster. Så skrev Carl följande:

Jag hade två kontaktmän plus att två flickor ifrån Jehova kom då och då. Dom började prat om andar. Min kontaktman hävdade att det kom ifrain min sjukdom. Jag bodde som sagt $i X$-stad då ibland var dom så otäcka som ex Dej ska jag ta först ska du bli bra. Jag ringde massvis med gainger till X-stadspolisen mitt $i$ nätterna. Jag sa att jag hade folk efter mig som skulle ta mej. Vi skickar en patrull. Jag had inget riktigt begrepp just då varifrån rösterna kom stundvis var jag riktigt rädd. en skötare sa en gång att det hänger ihop med Dietet jaget överjaget som inte, drar jämn. Nu börjar det avta. Men jag kan höra hu så du ser ut. Vi ger, oss inte vi vill se dej dö ut. Aldrig mer fitta på din kuk. Inte roligt ibland är jag skiträdd. Står $i$ kontakt med folk inom psykiatrin har en stödos medicin. Jag tror att denna gång kommer det att växa bort. ursch så du ser ut jag vill se dej dö ut en kvinnoröst säger så. Så vad ska man tro.

Det citerade avsnittet avslutade informantens brev. Ingenting gott kom tydligen av att höra röster. I brevets första del berättades, att Carl hörde röster i ungdomen, vilka försvann successivt genom medicinering. När en jämnårig vän dog, började han höra röster igen, men då hjälpte inte läkemedel. I stället ansatte de honom periodvis mycket hårt. Han hotades, han skulle dö eller aldrig mer ha ett sexualliv. Tillvaron var periodvis svåruthärdlig. Carls var mycket rädd för sina röster och kunde inte heller förklara, varifrån de kom. En människa kan överväldigas av inre röster, och av sina egna och andras tankar om dem. Det var, som om han måste beskriva allt samtidigt, så att läsaren skulle förstå det kaos som rådde. Texten var enkel, men informationstät. Den ena meningen efter den andra skapar intensitet. Han formulerade sig så att det blev ett myller. Texten var en inre dialog om inre röster och om egna och andras reaktioner och reflektioner, vilket blev tydligt, om olika repliker särskildes. Se tabell 2 .

I texten återfanns fragment från olika stämmor inom och utom informanten. I Carls medvetande fanns olika föreställningar om den inre världen, det var delvis andra människors röster om hans belägenhet. Texten var delvis dialogisk, därför att olika medvetanden ställdes mot varandra utan att bli objekt för varandra. Carl dramatiserade brevet genom att åberopa andra, verkliga människor, som två kontaktmän från psykiatrin. En av dem betecknade hans röster som symtom på psykisk ohälsa, således en medicinsk förklaring. En skötare gav i stället en psykoanalytisk förklaring till dem och sade, att Carl hörde röster, eftersom detet, jaget och överjaget inte drog jämnt. I en av meningarna blandades troligen de inre rösterna samman. Carl beskrev vad rösterna sade och refererade till någons försäkran att han nog skulle »bli bra». Två Jehovas vittnen föreslog övernaturliga tolkningar. När rösterna var hotfulla, begärde Carl hjälp av polisen. Vi inser hans oro, hans kamp för att få vara i fred, kanske därför att 
han varken förstod varifrån rösterna kom eller hur han skulle bemästra dem. Många av informanternas röster framstod som personligheter, som självständiga väsen som informanterna måste leva med, lyssna och tala till. De förblev då inte anonyma, utan fick namn eller benämningar. Kommunikationen med rösterna och mellan rösterna kan karakteriseras som dialoger, men något annat händer också i somliga texter, som i följande exempel, av Cecilia:

Mycket häpen och lite kuslig till mods kände jag mig en gång, när jag hörde "lilla gossen" läsa högt ur den bok jag låg och läste tyst för mig själv. Jag minns, att jag tänkte: - Det är underliga saker det här, som jag är med om. Kan det vara någon slags telepati? (...) - Då hörde jag "lilla gossen « säga: - Farmor, vet du vad telepati är? - Och "farmor" svarade med sin lugna, lite eftertänksamma röst: Jag har hört ordet, men jag kan inte säga riktigt, vad det är

Karaktärerna hade ett medvetande, oberoende av informantens. Deras uppfattning om världen och deras människosyn var inte informantens, utan självständiga, parallellt

\section{Tabell 2.}

Möjliga karaktärer

Två flickor ifrån Jehova

En kontaktman inom psykiatrin

Rösterna

Någon inom psykiatrin

Carl (kontaktade polisen nattetid)

Polisen

Carl

Skötare inom psykiatrin

Rösterna

Carl

Rösterna

Carl

\section{Brevtexten}

"började prat om andar"

whävdade att det (rösterna) kom ifrån min sjukdom"

var "så otäcka som ex Dej ska jag ta först"

"...ska du bli bra"

"Jag sa att jag hade folk efter mig som skulle ta mej."

„Vi skickar en patrull.»

"Jag had inget riktigt begrepp just då varifrån rösterna kom stundvis var jag riktigt rädd."

"det hänger ihop med Dietet jaget överjaget som inte drar jämt».

"hu så du ser ut. Vi ger, oss inte vi vill se dej dö ut. Aldrig mer fitta på din kuk.»

"Inte roligt ibland är jag skiträdd. Står i kontakt med folk inom psykiatrin har en stödos medicin. Jag tror att denna gång kommer det att växa bort." "ursch så du ser ut(,) jag vill se dej dö ut"

"Så vad ska man tro" 
med hennes egen. Begreppet polyfoni, flerstämmighet, kan karakterisera denna företeelse. Figurerna skildrades som tänkande »subjekt». De olika rösterna är och förblir självständiga. I Cecilias brev förde rösterna en dialog med varandra. I andras brev framgick inte alltid, om rösterna kommunicerade med varandra. Det finns en inneboende logik i vissa texter som handlade om att när olika röster stod för olika ståndpunkter, reflekterades olika medvetanden som inte kändes igen som ens eget jag. Detta stämde med Bachtins uppfattning, att varje tanke representerar ett mänskligt medvetande, eftersom varje tanke måste tillhöra någon (Bachtin, 1991).

Brevskrivaren satte in sina röster i ett biografiskt sammanhang. Dock föreslog rösterna en förklaring som hon först inte ville acceptera, nämligen att rösterna skulle vara hennes ofödda barns. Rösterna kunde bearbeta henne på olika sätt, de försökte "övertala» henne att kasta sig ut från en balkong. Cecilias attityd var inte bara passiv, utan hon lyssnade selektivt och tog ställning vartefter. Vi vill kanske betrakta röster som monologa till sin natur och rösthörare som offer för rösternas anstormning, vilket kanske kan bero på bristfällig kommunikation med rösthörare. Breven visade, att rösthörande i stället kan ha en dialog struktur.

\section{Sammanfattande diskussion}

Rösthörande är, enligt Al-Issa (1995), en allmänmänsklig erfarenhet. Inre röster kan uttrycka rösthörares personliga eller sociala problem (Romme \& Escher, 2000). De upplevs som främmande för jaget (ego-alien)
(Leudar et al,1997). De känns alltså inte som varande egna tankar. Röster uttrycker ett inre tal, är nyttiga för tankelivet och hjälper vid problemlösning (aa).

Föreliggande studie utgick från textanalytiska resonemang för att analysera självbiografiska brev om att höra röster, således undersöktes hur rösthörare strukturerade sina texter med hjälp av litterära konventioner, som relationen till tid och rum. De kunde exempelvis ordna händelserna som förknippades med rösthörande, tidmässigt och knöt rösterna till livsavgörande förändringar, som giftermål, skilsmässa, anhörigas död etc. Rösthörandet markerade därmed en övergång i livet. Andra rösthörare nämnde aldrig dimensionen tid, utan utgick från rummet, dvs. platsen, där allt utspelade sig. Berättare och röster eller andra personer rörde sig då in i och ut ur rummet eller den psykotiska världen.

När studien fokuserade på hur rösthörare framställde sina upplevelser, gavs en större förståelse för fenomenet. Nackdelen är att följdfrågor, för att få veta mer, inte kan ställas. Varje brev var en partsinlaga, ett personligt dokument och ett svar på en efterlysning. Alla breven var jagcentrerade. Flera informanter uppträdde som karaktärer i sin egen historia och beskrev hur rösterna talade till dem eller med varandra. Många röster framstod som personligheter, som självständiga väsen eller ständiga följeslagare, som informanterna måste leva med, lyssna till och kommunicera med.

En del röster var mer irrationella eller mer otidsenliga än andra, $t$ ex de som hade ett religiöst innehåll eller var svåra att tolka. Även om texterna var sekulariserade, 
användes i några ord med religiös klang, som att rösten var (som) en biktfader, en plågoande eller en demon. Vissa brev skulle kunna inordnas i en västerländsk tradition av texter om introspektion, vansinne och frälsning eller i en tradition av andliga självbiografier.

Gränserna mellan tankar och röster var inte alltid så tydliga. Breven visade att röster ibland är en exceptionell form av människors inre tal (Leudar et al, 1997)). Termerna monolog, dialog, polyfoni och kakofoni karakteriserade varianter av rösthörande, men också att berättelserna om dem kunde karakteriseras likadant. Att använda Bachtins (1991) litterära begrepp för att analysera självbiografiska texter om rösthörande gav ny kunskap om fenomenet. Uppfattningen om röster som monologa, dvs. att de utan någon kontext kommenterar eller kommenderar rösthöraren visade sig inte vara hållbar. Tvärtom har rösthörande en dialog struktur. Rösthörarna var inte passiva, utan lyssnade selektivt till sina röster.

Breven kunde uppfattas som informanternas försök att hitta en genre för att göra sin historia begriplig, inte i första hand för att redovisa sanna upplevelser, utan för att finna en mening med eller tillfälligt summera sina livserfarenheter. Informanterna tycktes söka ett användbart språk för att gestalta rösthörandet. Med ett sådant kanske rösthörare kan skaffa sig en social identitet och påverka andra mot större förståelse för företeelsen. Åtminstone i denna studie ville de meddela sig, att döma av den rikliga förekomsten av dialogiska grepp. Att kommunicera om ovanliga upplevelser är möjligt om en särskild berättarstil används, som beskrivningar om det "psykotiska rummet». En människa begränsas av språket, men kan också med detta beskriva och bemästra sitt lidande. Kan hon gå in i »det psykotiska rummet", så kan hon också gå ur det igen och därmed återhämta sig.

\section{Litteratur}

Adler, M. (1997). Where do voices come from? Journal of the Royal Society of Medicine, 90, 28-32.

Al-Issa, I. (1977). Sociocultural Factors in Hallucinations. Psychological Bulletin, 84, 167-176.

Al-Issa, I. (1995). The Illusion of Reality or the Reality of Illusion. Hallucinations and Culture. British Journal of Psychiatry, 166, 368-373.

Assad, G. \& Shapiro, B. (1986). Hallucinations:
Theoretical and Clinical Overview. American Journal of Psychiatry, 143, 1088-1097.

Aronowitz, S. (1995). Literature as Social Knowledge: Mikhail Bakhtin and the Reemergence of the Human Sciences. In Mandelker, A. (Ed.) Bakhtin in Contexts. Across the Disciplines. (pp. 119-135). Evanston, Illinois: Northwestern University Press. 
Bachtin, M.M. (1991). Dostojevskijs poetik. Gråbo: Anthropos.

Barrett, T.R. \& Etheridge, J.B. (1992). Verbal Hallucations in Normals, I: People who Hear "Voices". Applied Cognitive Psychology, 6, 379-387.

Bentall, R.P. (1993). Deconstructing the Concept of "Schizophreniaw. Journal of Mental Health, 2, 223-238.

Boyle, M. (1993). Schizophrenia: A Scientific Delusion? London: Routledge.

Ensink, B. (1993). Trauma: A Study of Child Abuse and Hallucinations. In Romme, M., \& Escher, S. (Eds.). Accepting Voices. (pp. 165-171). London: Mind publications.

Geels, A. (1991). Att möta Gud i kaos. Religiösa visioner i dagens Sverige. Stockholm: Norstedts.

Foucault, M. (1986). Vansinnets historia under den klassiska epoken. Malmö: Arkiv moderna klassiker.

Grimby, A. (1995). Lurad av minnen och sina sinnen? Änkesyner vanliga vid stor sorg och saknad. Läkartidningen, 92, 4878-4881.

Grof, C. \& Grof, S. (1990). The Stormy Search for the Self: A Guide to Personal Growth through Transformational Crisis. Los Angeles: Tarcher.

Grof, S. \& Grof, C. (1989). (Eds.). Spiritual Emergency: When Personal Transformation Becomes a Crisis. Los Angeles: Tarcher.

Hammersley, M. \& Atkinson, P. (1995). Ethnography. Principles in Practice. Second edition. London \& New York: Routledge.

Hillerdal, G. (1988). Så ger sig Gud till känna. Om gudserfarenheter i vår tid. Stockholm: Proprius förlag.

La Barre, W. (1975). Anthropological Perspectives on Hallucination and Hallucinogens. In Siegel, R. K. \& West, L.J. (Eds.) Hallucinations: Behavior, Experience, and Theory.(pp. 9-52.) New York: John Wiley \& Sons, Inc.

Leudar, I., Thomas, P., \& Johnston, M. (1992). Selfrepair in Dialogues of Schizophrenics: Effects of Hallucinations and Negative Symptoms.
Brain and Language, 43, 487-511.

Leudar, I., Thomas, P., \& Johnston, M. (1994). SelfMonitoring in Speech Production: Effects of Verbal Hallucinations and Negative Symptoms. Psychological Medicine, 24, 749-761.

Leudar, I., Thomas, P., McNally, D., \& Glinski, A. (1997). What Voices Can Do with Words: Pragmatics of Verbal Hllucinations. Psychological Medicine, 27, 885-898.

Leudar, I. \& Thomas, P. (2000). Voices of Reason, Voices of Insanity. Studies of Verbal Hallucinations. London: Routledge.

Malterud, K. (1998). Kvalitativa metoder $i$ medicinsk forskning. Lund: Studentlitteratur.

Mishler, E. G. (1986). Research Interviewing. Context and Narrative. Cambridge \& London: Harvard University Press.

Nayani, T.H. \& David, A.S. (1996). The Auditory Hallucination: A Phenomenological Survey. Psychological Medicine, 26, 177-189.

O'Mahony, M., Shulman, K. \& Silver, D. (1984). Roses in December: Imaginary Companions in the Elderly. Canadian Journal of Psychiatry, $29,151-154$.

Posey, T.B., \& Losch, M.E. (1983). Auditory Hallucinations of Hearing Voices in 375 Normal subjects. Imagination, Cognition and Personality, 2, 99-113.

Rees, W.D. (1971). The hallucinations of Widowhood. British Medical Journal, 4, 37-41.

Romme, M. \& Escher, S. (1989). Hearing Voices. Schizophrenia Bulletin, 15, 209-216.

Romme, M. \& Escher, S. (2000). Making Sense of Voices. The Mental Health Professional's Guide to Working with Voice-Hearers. London: Mind Publications.

Slade, P.D. \& Bentall, R.P. (1988). Sensory Deception. A Scientific Analysis of Hallucination. London \& Sydney: Croom Helm.

Tien, A.Y. (1991). Distribution of Hallucinations in the Population. Social Psychiatry and Psychiatric Epidemiology, 26, 287-292. 


\section{Summary}

\section{Hearing voices: personal letters about voices}

This article analyses personal letters written by 41 voice hearers ( 26 men, 19 women) collected 1998-2000 through newspaper advertisements and appeals. The respondents wrote about how they acted as characters in their own story and how the voices spoke to them or to each other. The voices were described as dialogical or polyphonic. Also the stories were characterized in the same way. The letters can be seen as part of a western tradition of autobiographic texts about introspection and madness. The texts sometimes had a religious tone, using words such as confessor, demon or tormentor. Judging by the abundant use of dialogic devices the voice hearers were eager to communicate. The texts showed that communication is possible through the use of a specific style, such as talking about "the psychotic room". If people tend to be limited by their language, they can also use it to describe and handle difficulties in life. If one can enter "the psychotic room", it is also possible to leave it and consequently to recover. 